\title{
Effects of the Prostaglandins on Hormone-induced Mobili- zation of Free Fatty Acids *
}

\author{
Daniel Steinberg, Martha Vaughan, Paul J. Nestel, $†$ Ove Strand, $\ddagger$ and \\ Sune Bergström \\ (From the Laboratory of Metabolism, National Heart Institute, Bethesda, Md., and the \\ Department of Chemistry, Karolinska Institutet, Stockholm, Sweden)
}

About 30 years ago, Goldblatt $(1,2)$ and von Euler $(3,4)$ showed that human and ovine seminal plasma contain an acidic lipid (prostaglandin) with vasodepressor activity and smooth muscle-stimulating activity. The early studies have been summarized by von Euler $(5,6)$. In 1960 Bergström and Sjövall isolated from sheep vesicular glands a highly potent crystalline material, prostaglandin $\mathrm{E}_{1}\left(\mathrm{PGE}_{1}\right)(7){ }^{1}$ The structure of this compound (Figure 1) was established as 2 (6-carboxyhexyl)-3-(3-hydroxyocten-1-yl)-4-hydroxycylopentanone (8) or $11 \alpha, 15$-dihydroxy-9-ketoprost-13-enoic acid. Further studies showed that two closely related active compounds, $\mathrm{PGE}_{2}$ and $\mathrm{PGE}_{3}$, differing in having one and two additional double bonds, respectively, are also present in sheep vesicular glands (9). Human semen contains approximately equal amounts of these three prostaglandins (10), and $\mathrm{PGE}_{1}$ has been demonstrated in the calf thymus (11). The corresponding compounds in which the keto group of the $\mathrm{E}$ compounds has been reduced to an alcohol group $\left(\mathrm{PGF}_{1 \alpha}, \mathrm{PGF}_{2 \alpha}\right.$, and $\left.\mathrm{PGF}_{3 \alpha}\right)$ have been isolated in small amounts from seminal plasma, and $\mathrm{PGF}_{2 \alpha}$ has been isolated from lungs of sheep and pig (12) and from sheep iris (13).

The high concentration of prostaglandin in seminal plasma suggested that its primary role would be in relation to sexual function, perhaps facilitating passage of sperm up the genital tract by relaxing the uterus (5). On the other hand, the presence of prostaglandins has now been es-

\footnotetext{
* Submitted for publication September 23, 1963; accepted March 19, 1964.

† Present address: Department of Medicine, Royal Melbourne Hospital, Melbourne, Australia.

$\ddagger$ Deceased, September 15, 1963.

1 Abbreviations used: $\mathrm{PG}=$ prostaglandin $\left(\mathrm{PGE}_{1}=\right.$ prostaglandin $\mathrm{E}_{1}, \mathrm{PGE}_{2}=$ prostaglandin $\mathrm{E}_{2}$, etc.) and $\mathrm{TSH}=$ thyroid-stimulating hormone.
}

tablished in a variety of other tissues. Whereas the concentrations found are very low, the compounds are extremely potent vasodepressor agents in man and in experimental animals $(6,14)$, and a more general physiological function for these unusual compounds remains a possibility.

The present studies show that very low concentrations of $\mathrm{PGE}_{1}$ inhibit glycerol production in adipose tissue and counteract the stimulation of glycerol release induced by catecholamines, glucagon, ACTH, and TSH. This is shown to be due to an interference with the activation of tissue lipase usually produced by exposure of adipose tissue to these hormones. The relative potencies of the several prostaglandins is compared. The vasopressor effects of epinephrine or norepinephrine in dogs are also shown to be blocked by $\mathrm{PGE}_{1}$. A preliminary report of this work has appeared elsewhere (15).

\section{Methods}

The methods and materials used in the in vitro studies have been described in previous papers $(16,17)$. Briefly, epididymal fat pads were taken from SpragueDawley rats (150 to $200 \mathrm{~g}$ ) fed ad libitum until killed by decapitation. Tissues were incubated 1 hour at $37^{\circ} \mathrm{C}$

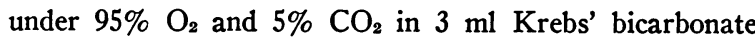
medium containing bovine serum albumin (30 $\mathrm{mg}$ per $\mathrm{ml}$ ). Glucose was not added to the medium. Glycerol was determined by Korn's modification (18) of the method of Lambert and Neish (19). FFA were determined by Dole's method (20), using isooctane in place of heptane.

Tissue phosphorylase was assayed in homogenates prepared at the end of the incubation by methods previously described (21). Lipase activity in the same homogenates was assayed by methods shown in previous studies to maximize the effects of epinephrine $(22,23)$. The tissue was homogenized in 10 vol of $0.154 \mathrm{M} \mathrm{KCl}$, and suitable samples were added to an incubation mixture containing $30 \mathrm{mg}$ bovine serum albumin and $20 \mu$ moles of sodium phosphate buffer, $\mathrm{pH} 7.0$, in a final volume of 1.0 


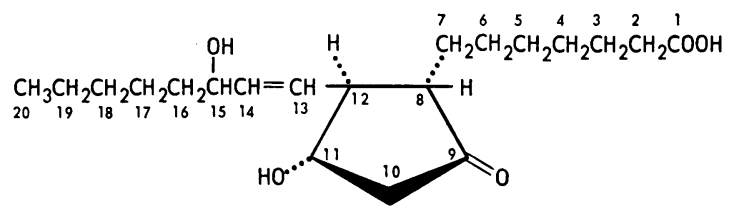

PROSTAGLANDIN E,

Fig. 1. Structure of PGE,. Reduction of the keto group at position 9 yields $\mathrm{PGF}_{1}$, which can exist in two stereoisomeric forms-PGF $1 \alpha$ and $\mathrm{PGF}_{1 \beta}$. $\mathrm{PGE}_{2}$ differs from $\mathrm{PGE}_{1}$ only in having an additional double bond at the 5,6 position; $\mathrm{PGE}_{3}$ has an additional double bond at 5,6 and at 17,18. $\mathrm{PGF}_{2}$ and $\mathrm{PGF}_{3}$ are the 9-hydroxy compounds analogous to $\mathrm{PGF}_{1}$.

ml. The reaction was stopped by addition of $1 \mathrm{ml}$ of a mixture containing ethanolamine $(0.9 \mathrm{M})$, acetic acid $(0.1 \mathrm{M})$, and $\mathrm{Cu}\left(\mathrm{NO}_{3}\right)_{2} \cdot 3 \quad \mathrm{H}_{2} \mathrm{O} \quad(5 \%)$. The copper salts of the fatty acids were extracted into chloroform, and the amount of copper present in the chloroform was determined colorimetrically. This procedure, adapted from the method described by Duncombe (24), was described in detail in an earlier publication from this laboratory (23).

Mongrel dogs were anesthetized with intravenous pentobarbital. Mean femoral arterial pressure was monitored continuously with a Statham strain gauge. Catecholamines and prostaglandins were administered by a femoral vein catheter, and blood samples for analysis were drawn from a catheter in the opposite femoral artery advanced into the aorta. Blood glucose was determined with glucose oxidase. ${ }^{2}$ Plasma FFA were determined by Dole's method (20).

The prostaglandin preparations were fully characterized crystalline compounds isolated from sheep prostate glands and, .in some cases, chemically modified as described elsewhere (7-9). Stock solutions in ethanol were stored at $-10^{\circ} \mathrm{C}$ and diluted in saline or in buffers before use. The final incubation medium contained $0.002 \%$ ethanol both in control and experimental flasks. The structure of $\mathrm{PGE}_{1}$ is shown in Figure 1. $\mathrm{PGE}_{2}$ differs from it only in having an additional double bond in the 5,6 position, whereas $\mathrm{PGE}_{3}$ has additional double bonds at both the 5,6 and the 17,18 positions. The compounds of the $F$ series are analogous to those of the E series except that the 9-keto group has been reduced to a hydroxyl group. The suffixes $\alpha$ and $\beta$ denote the stereoisomeric configuration of this hydroxyl group.

\section{Results}

In vitro release of glycerol from fat pad. As shown in Table I, $\mathrm{PGE}_{1}$ alone $(0.1 \mu \mathrm{g}$ per $\mathrm{ml})$ significantly reduced basal glycerol release from

\footnotetext{
2 Glucostat reagents, Worthington Biochemical Corp., Freehold, N. J.
}

adipose tissue. At this same low concentration it markedly reduced the stimulating effects of epinephrine, norepinephrine, glucagon, and ACTH. The effect of TSH was not significantly inhibited when $\mathrm{PGE}_{1}$ was added only at the start of the 1-hour incubation, as in the other studies. When, however, a second addition of $0.1 \mu \mathrm{g} \mathrm{PGE}_{1}$ per ml was made after 30 minutes of incubation, there was a significant suppression of the TSH effect.

$\mathrm{PGE}_{2}$ was also effective in counteracting the epinephrine stimulation of glycerol release, but appeared to be less effective than $\mathrm{PGE}_{1}$ (Table II). Because of the considerable variation in response to hormone stimulation observed in tissues from different rats, it is difficult to compare the potency of inhibitors studied in separate experiments. A direct comparison of potencies was made by incubating both fat pads from a single rat with the lipolytic hormone and adding $\mathrm{PGE}_{1}$ to one flask, $\mathrm{PGE}_{2}$ to the other. The results of this direct comparison, shown in Table III, indicated that $\mathrm{PGE}_{2}$ was less potent than $\mathrm{PGE}_{1}$ in antagonizing the action of ACTH and glucagon. The difference in the case of the epinephrine experiments was of borderline significance.

$\mathrm{PGE}_{3}$ at $0.1 \mu \mathrm{g}$ per $\mathrm{ml}$ did not suppress the action of epinephrine, $\mathrm{ACTH}$, or glucagon (Table II). At 10 times this concentration, there was still no inhibition in the presence of epinephrine. A very high concentration of $\mathrm{PGE}_{3}, 16.6 \mu \mathrm{g}$ per $\mathrm{ml}$, significantly suppressed the activity of epinephrine present at a concentration of $0.1 \mu \mathrm{g}$ per ml.

TABLE I

Effects of prostaglandin $E_{1}\left(P G E_{1}\right)$ on hormone-stimulated glycerol release from rat epididymal fat pads*

\begin{tabular}{|c|c|c|c|}
\hline \multirow[b]{2}{*}{ Hormone added } & \multicolumn{3}{|c|}{ Glycerol release } \\
\hline & $\begin{array}{l}\text { Without } \\
\text { PGE }_{1}\end{array}$ & $\begin{array}{c}\Delta \text { due to } \\
\mathrm{PGE}_{1} \dagger\end{array}$ & $p$ value \\
\hline & \multicolumn{3}{|c|}{$\mu$ moles $/ \mathrm{g} / \mathrm{hr}$} \\
\hline Nonet & 0.9 & $-0.3 \pm 0.06$ & $<0.001$ \\
\hline Epinephrine, $0.1 \mu \mathrm{g} / \mathrm{ml}$ & 3.1 & $-1.5 \pm 0.38$ & $<0.01$ \\
\hline Norepinephrine, $0.2 \mu \mathrm{g} / \mathrm{ml}$ & 5.5 & $-2.2 \pm 0.13$ & $<0.001$ \\
\hline Glucagon, $5 \mu \mathrm{g} / \mathrm{ml}$ & 3.1 & $-1.6 \pm 0.27$ & $<0.002$ \\
\hline ACTH, $0.04 \mathrm{U} / \mathrm{ml}$ & 4.6 & $-1.6 \pm 0.21$ & $<0.001$ \\
\hline $\mathrm{TSH}, 10 \mu \mathrm{g} / \mathrm{mls}$ & 3.0 & $-0.3 \pm 0.2$ & NS \\
\hline $\mathrm{TSH}, 10 \mu \mathrm{g} / \mathrm{ml} \|$ & 4.7 & $-1.5 \pm 0.27$ & $<0.005$ \\
\hline
\end{tabular}

* Six pairs of tissues in each hormone study were incubated for 1 hour in $3 \mathrm{ml}$ Krebs' bicarbonate medium containing bovine serum albumin, $30 \mathrm{mg}$ per $\mathrm{ml}$, in an atmosphere of $95 \%$ oxygen and $5 \%$ carbon dioxide. Hormones were added to both flasks; $\mathrm{PGE}_{1}(0.1 \mu \mathrm{g}$ per $\mathrm{ml})$ to only one. $\dagger$ Mean of differences between paired tissues \pm standard error of the mean.

\pm Data from 16 pairs of tissues.

TSH = thyroid-stimulating hormone.

$\mathrm{TSH}_{1}, 0.1 \mu \mathrm{g}$ per ml, added at zero time and again after 30 minutes.
$\mathrm{PG}, \mathrm{a}$ 
TABLE II

Effects of $P G E_{2}, P G F_{2 \alpha}$, and $P G E_{3}$ on hormone-stimulated glycerol release from fat pad*

\begin{tabular}{|c|c|c|c|c|}
\hline \multirow[b]{2}{*}{$\begin{array}{l}\text { Lipolytic } \\
\text { hormone } \\
\text { added }\end{array}$} & \multirow[b]{2}{*}{$\begin{array}{c}\text { Prostaglandin compound } \\
\text { added }\end{array}$} & \multicolumn{2}{|c|}{ Glycerol release } & \multirow[b]{2}{*}{ p value } \\
\hline & & $\begin{array}{l}\text { Without } \\
\text { PG com- } \\
\text { pound }\end{array}$ & $\begin{array}{l}\Delta \text { due to } P G \\
\text { compound } f\end{array}$ & \\
\hline \multicolumn{5}{|c|}{ Mmoles $/ \mathrm{g} / \mathrm{hr}$} \\
\hline $\begin{array}{c}\text { Epinephrine, } \\
0.1 \mu \mathrm{g} / \mathrm{ml}\end{array}$ & $\mathrm{PGE}_{2}, 0.1 \mu \mathrm{g} / \mathrm{ml}(6) \ddagger$ & 4.4 & $-1.8 \pm 0.78$ & $<0.1$ \\
\hline Epinephrine, & & & $-1.0 \pm 0.10$ & 0.1 \\
\hline $\begin{array}{c}0.1 \mu \mathrm{g} / \mathrm{ml} \\
\text { Epinephrine }\end{array}$ & $\mathrm{PGE}_{2}, 0.5 \mu \mathrm{g} / \mathrm{ml}(10)$ & 4.12 & $-0.80 \pm 0.13$ & $<0.001$ \\
\hline $0.1 \mu \mathrm{g} / \mathrm{ml}$ & $\mathrm{PGF}_{2 \alpha}, 0.5 \mu \mathrm{g} / \mathrm{ml}(12)$ & 4.14 & $-0.37 \pm 0.18$ & NS \\
\hline $\begin{array}{l}\text { Epinephrine, } \\
0.1 \mu \mathrm{g} / \mathrm{ml}\end{array}$ & $\mathrm{PGE}_{2}, 5.0 \mu \mathrm{g} / \mathrm{ml}(6)$ & 4.02 & $-1.87 \pm 0.26$ & $<0.001$ \\
\hline $\begin{array}{l}\text { Epinephrine, } \\
0.1 \mu \mathrm{g} / \mathrm{ml}\end{array}$ & $\mathrm{PGF}_{2 \alpha}, 5.0 \mu \mathrm{g} / \mathrm{ml}(6)$ & 3.52 & $-1.42 \pm 0.31$ & $<0.01$ \\
\hline $\begin{array}{l}\text { Epinephrine, } \\
0.1 \mu \mathrm{g} / \mathrm{ml}\end{array}$ & $\mathrm{PGE}_{3}, 0.1 \mu \mathrm{g} / \mathrm{ml}(6)$ & 4.62 & $-0.01 \pm 0.20$ & NS \\
\hline Epinephrine, & $\mathrm{PGE}_{3}, 1.0 \mu \mathrm{g} / \mathrm{ml}(6)$ & 3.62 & $-0.45 \pm 0.20$ & NS \\
\hline $\begin{array}{l}\text { Epinephrine, } \\
0.1 \mu \mathrm{g} / \mathrm{ml} \\
\text { АСТH, }\end{array}$ & $\mathrm{PGE}_{3}, 16.6 \mu \mathrm{g} / \mathrm{ml}(6)$ & 2.40 & $-0.91 \pm 0.20$ & $<0.01$ \\
\hline $\begin{array}{l}0.04 \mathrm{U} / \mathrm{ml} \\
\mathrm{ACTH}\end{array}$ & $\mathrm{PGE}_{2}, 0.1 \mu \mathrm{g} / \mathrm{ml}(6)$ & 4.6 & $-0.2 \pm 0.3$ & NS \\
\hline $0.04 \mathrm{U} / \mathrm{ml}$ & $\mathrm{PGE}_{3}, 0.1 \mu \mathrm{g} / \mathrm{ml}(6)$ & 4.67 & $-0.72 \pm 0.57$ & NS \\
\hline $5 \mu \mathrm{g} / \mathrm{ml}$ & $\mathrm{PGE}_{3}, 0.1 \mu \mathrm{g} / \mathrm{ml}(6)$ & 1.31 & $-0115 \pm 0.16$ & NS \\
\hline
\end{tabular}

* Incubations were carried out as described in the footnote for Table I.

$\dagger$ Mean of differences between paired tissues \pm standard error of the mean.

$\ddagger$ The number of pairs of tissues in each group is indicated in parentheses.

The activities of $\mathrm{PGE}_{1}$ and its derivatives, $\mathrm{PGF}_{1 \alpha}$ and $\mathrm{PGF}_{1 \beta}$, are compared in Table IV. At $0.5 \mu \mathrm{g}$ per $\mathrm{ml}$ the $\mathrm{F}$ derivatives had no significant effects on epinephrine-induced glycerol release. At $5 \mu \mathrm{g}$ per $\mathrm{ml}, \mathrm{PGF}_{1 \alpha}$ had a small effect, but $\mathrm{PGF}_{1 \beta}$ was still inactive.

The activities of $\mathrm{PGE}_{2}$ and its derivative $\mathrm{PGF}_{2 \alpha}$ can be compared in Table II. At a concentration of $0.5 \mu \mathrm{g}$ per $\mathrm{ml}, \mathrm{PGE}_{2}$ had a highly significant effect in the presence of epinephrine, whereas $\mathrm{PGF}_{2 \alpha}$ was ineffective. At a tenfold higher concentration $\mathrm{PGF}_{2 \alpha}$ had a significant suppressive effect. A direct comparison of $\mathrm{PGE}_{2}$ and $\mathrm{PGF}_{2 \alpha}$ in paired tissues, both exposed to epinephrine as discussed above, showed that the $\mathrm{F}$ derivative was distinctly less potent (Table III).

In many of the studies summarized above, FFA release into the medium was also measured. The

TABLE III

Direct comparison of inhibiting activities of PG compounds on hormone-stimulated glycerol release*

\begin{tabular}{|c|c|c|c|c|}
\hline $\begin{array}{l}\text { Hormone added } \\
\text { in both flasks }\end{array}$ & $\begin{array}{l}\text { PG compound in } \\
\text { flask } \mathrm{A}\end{array}$ & $\begin{array}{l}P G \text { compound in } \\
\text { flask B }\end{array}$ & $\begin{array}{c}\text { Difference in } \\
\text { glycerol release } \\
\text { A - B }\end{array}$ & p value \\
\hline \multirow{5}{*}{$\begin{array}{c}\text { Epinephrine, } \\
0.1 \mu \mathrm{g} / \mathrm{ml} \\
\text { ACTH, } \\
0.04 \mathrm{U} / \mathrm{ml} \\
\text { Glucagon, } \\
5 \mu \mathrm{m} / \mathrm{ml} \\
\text { Epinephrine, } \\
0.1 \mu \mathrm{g} / \mathrm{ml}\end{array}$} & & \multicolumn{3}{|c|}{$\mu$ mole $/ \mathrm{g} / \mathrm{hr}$} \\
\hline & $\mathrm{PGE}_{1}, 0.1 \mu \mathrm{g} / \mathrm{ml}$ & $\mathrm{PGE}_{2}, 0.1 \mu \mathrm{g} / \mathrm{ml}$ & $-0.9 \pm 0.4$ & $<0.1$ \\
\hline & $\mathrm{PGE}_{1}, 0.1 \mu \mathrm{g} / \mathrm{ml}$ & $\mathrm{PGE}_{2}, 0.1 \mu \mathrm{g} / \mathrm{ml}$ & $-0.4 \pm 0.12$ & $<0.02$ \\
\hline & $\mathrm{PGE}_{1}, 0.1 \mu \mathrm{g} / \mathrm{ml}$ & $\mathrm{PGE}_{2}, 0.1 \mu \mathrm{g} / \mathrm{ml}$ & $-1.3 \pm 0.17$ & $<0.001$ \\
\hline & $\mathrm{PGE}_{2}, 2 \mu \mathrm{g} / \mathrm{ml}$ & $\mathrm{PGF}_{2 \alpha}, 2 \mu \mathrm{g} / \mathrm{ml}$ & $-0.73 \pm 0.25$ & $<0.05$ \\
\hline
\end{tabular}

* Six pairs of fat pads in each experiment. Hormones were added at concentrations indicated to both flasks. Prostaglandin compounds to be compared for potency were added respectively to flask A and to flask B. A negative value $(\mathrm{A}-\mathrm{B})$ indicates that the prostaglandin compound in flask A more effectively blocked glycerol production.

$\dagger$ Mean of differences between paired tissues \pm standard error of the mean. 


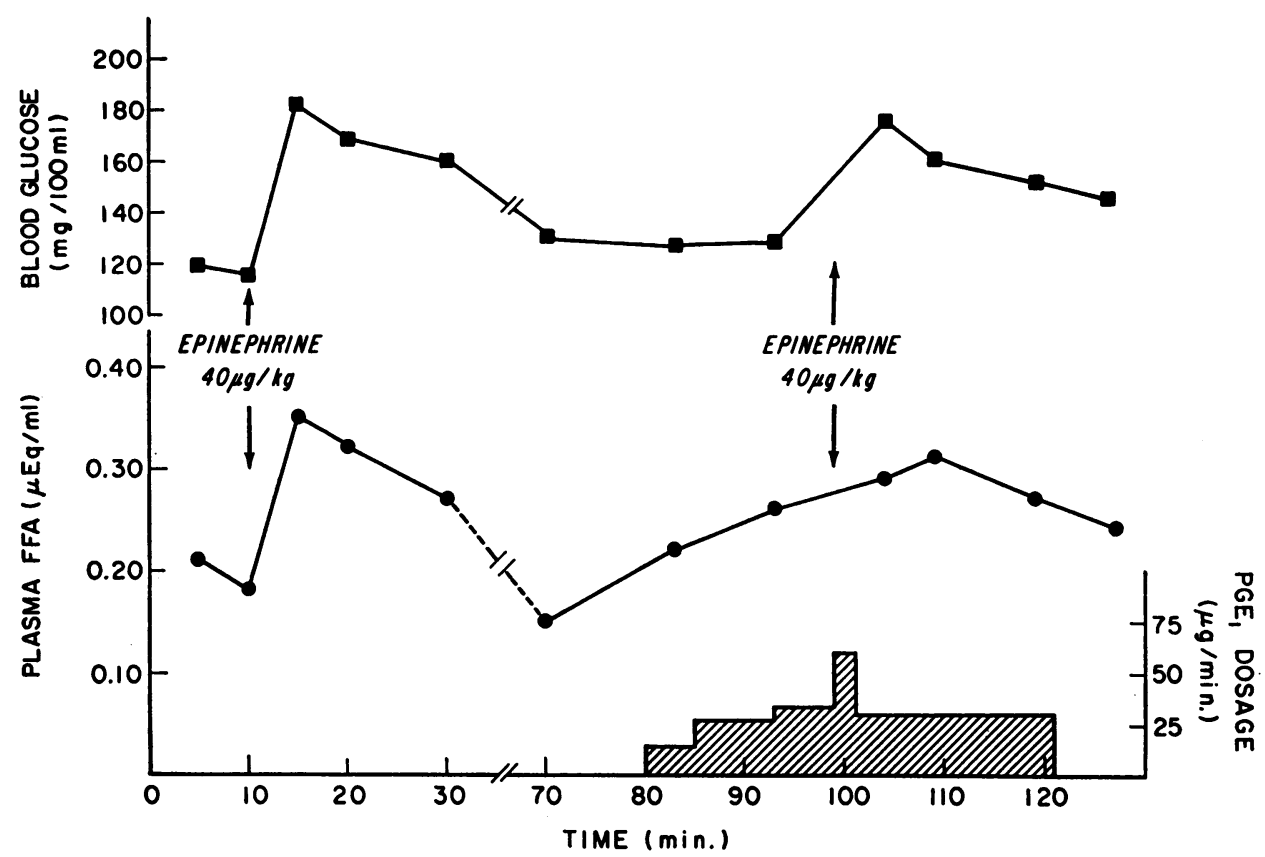

Fig. 2. Changes in blood glucose and plasma FFA levels induced in a 15.4-KG DOG BY EPINEPHRINE IN A CONTROL PERIOD AND DURING INFUSION OF PGE 1 (indicated by crosshatched area).

results generally paralleled closely those obtained for glycerol. An important exception was encountered in the studies of the effect of $\mathrm{PGE}_{1}$ in the absence of any added lipolytic hormones. Here there was no significant effect on basal FFA release even though, as shown in Table I, a significant suppression of basal glycerol release could be demonstrated.

TABLE IV

Comparison of inhibitory activities of $P G E_{1}$ and of its $P G F$ derivatives on epinephrine-stimulated glycerol release*

\begin{tabular}{lccc}
\hline \hline & \multicolumn{3}{c}{ Glycerol release } \\
\cline { 2 - 3 } $\begin{array}{c}\text { Concentration of } \\
\text { prostaglandin } \\
\text { derivative }\end{array}$ & $\begin{array}{c}\text { Without } \\
\text { PG }\end{array}$ & $\begin{array}{c}\Delta \text { release due } \\
\text { to PG }\end{array}$ & p value \\
\hline & & $\mu$ moles $/ \mathrm{g} / \mathrm{hr}$ & \\
$\mathrm{PGE}_{1}, 0.5 \mu \mathrm{g} / \mathrm{ml}$ & 1.83 & $-1.13 \pm 0.16$ & $<0.01$ \\
$\mathrm{PGF}_{1 \alpha}, 0.5 \mu \mathrm{g} / \mathrm{ml}$ & 1.89 & $-0.37 \pm 0.41$ & $\mathrm{NS}$ \\
$\mathrm{PGF}_{1 \beta}, 0.5 \mu \mathrm{g} / \mathrm{ml}$ & 2.16 & $-0.62 \pm 0.69$ & $\mathrm{NS}$ \\
& & & \\
$\mathrm{PGE}_{1}, 5 \mu \mathrm{g} / \mathrm{ml}$ & 6.76 & $-3.55 \pm 0.42$ & $<0.005$ \\
$\mathrm{PGF}_{1 \alpha}, 5 \mu \mathrm{g} / \mathrm{ml}$ & 3.97 & $-0.68 \pm 0.21$ & $>0.05$ \\
$\mathrm{PGF}_{1 \beta}, 5 \mu \mathrm{g} / \mathrm{ml}$ & 3.80 & $+0.04 \pm 0.29$ & $\mathrm{NS}$ \\
\hline
\end{tabular}

* Four pairs of fat pads in each experiment. All flasks contained epinephrine, $0.1 \mu \mathrm{g}$ per ml. Experimental flasks contained in addition the indicated prostaglandin derivative.

$\dagger$ Mean of differences between paired tissues \pm standard error of the mean.
Changes in tissue lipase and phosphorylase activity. Vaughan has shown that epinephrine and several other lipolytic hormones can activate adipose tissue phosphorylase (21). These hormones have also been shown to activate lipase system in adipose tissue $(22,23,25-27)$. With methods described previously (23), it was shown that the degree of lipase activation induced by epinephrine was decreased by adding $\mathrm{PGE}_{1}$ along with the epinephrine (Table V). The activation of phosphorylase in these same experiments was also significantly reduced. In these studies, the $\mathrm{PGE}_{1}$ effect was evaluated directly by using paired tissues both of which were exposed to epinephrine. The magnitude of the epinephrine-induced enzyme activation can therefore be estimated only by reference to other similar studies $(21,23)$. Such a comparison suggests that the effect on phosphorylase activation was smaller than that on lipase activation.

In vivo studies in anesthetized dogs. Intravenous injection of epinephrine ( $40 \mu \mathrm{g}$ per $\mathrm{kg}$ ) into an anesthetized dog caused the expected rise in plasma FFA and blood glucose levels (Figure 2 ). When the same dose of epinephrine was repeated while maintaining an intravenous infusion 


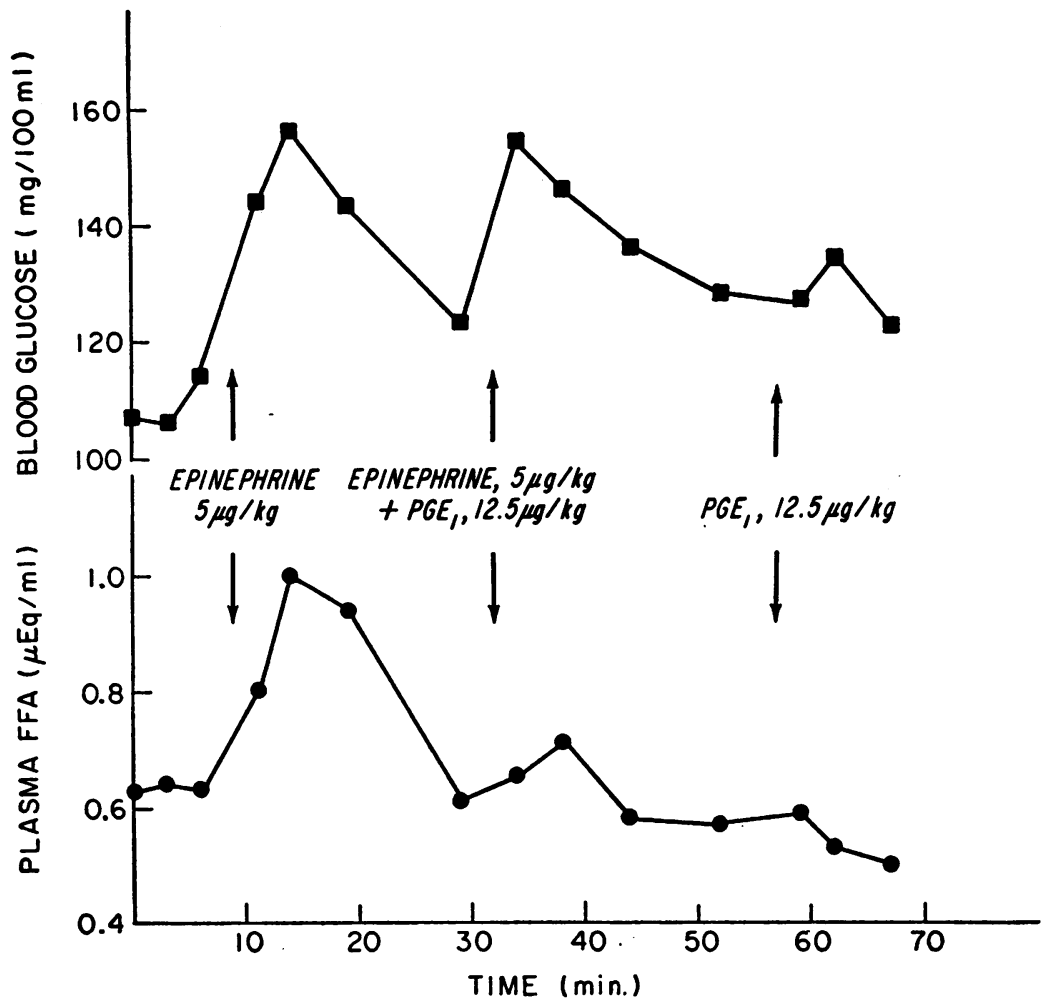

Fig. 3. Changes in blood glucose and plasma FFA levels induced in a 13 KG DOG BY INJECTION OF EPINEPHRINE ALONE, BY SIMULTANEOUS INJECTION

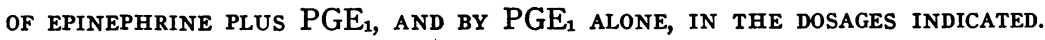

of $\mathrm{PGE}_{1}$ at the rates shown in Figure 2, the peak of the glucose response was comparable to that observed initially, but there was little or no change in plasma FFA.

Figure 3 shows the responses to a single intravenous injection of epinephrine, $5 \mu \mathrm{g}$ per $\mathrm{kg}$, given alone and then repeated with $12.5 \mu \mathrm{g}$ per $\mathrm{kg}$ of $\mathrm{PGE}_{1}$ injected simultaneously. Again the glucose response was apparently not altered while the FFA response was all but abolished. Injection of $\mathrm{PGE}_{1}$ alone in this case was followed by a slight fall in the FFA level, but no definite change in blood glucose level.

Intravenous injection of $\mathrm{PGE}_{1}$ alone, $12.5 \mu \mathrm{g}$ per $\mathrm{kg}$, caused a prompt fall in mean femoral arterial pressure from 100 to $60 \mathrm{~mm} \mathrm{Hg}$, with a return to control level by 2 minutes. In the same animal, epinephrine alone elevated mean pressure from 100 to approximately $180 \mathrm{~mm} \mathrm{Hg}$. When both compounds were simultaneously administered at these same dosages, the pressure rose to 150 $\mathrm{mm} \mathrm{Hg}$. A number of such studies were per- formed at various dose ratios of prostaglandin to epinephrine. At ratios of 2 or 3 to $1, \mathrm{PGE}_{1}$ consistently reduced and sometimes abolished the pressor response to epinephrine. At higher ratios there was a transient rise in mean pressure, per-

TABLE $\mathbf{V}$

Effects of $P G E_{1}$ on epinephrine-induced changes in adipose tissue lipase and phosphorylase activities*

\begin{tabular}{lcc}
\hline \hline & $\begin{array}{c}\text { Without } \\
\text { PGE }\end{array}$ & PGE effect $\dagger$ \\
\hline $\begin{array}{c}\text { Lipase activity, } \\
\mu \text { Eq FFA/g/20 min } \\
\begin{array}{c}\text { Phosphorylase artivity, } \\
\mu \text { moles P/g/30 min }\end{array}\end{array}$ & 5.1 & $-2.0 \pm 0.58$ \\
& 48.6 & $-3.5 \pm 0.73$
\end{tabular}

* Paired epididymal fat pads were incubated for 2 hours in $3 \mathrm{ml}$ Krebs' bicarbonate buffer containing $3 \%$ bovine serum albumin. Three minutes before the end of the incubation, epinephrine was added to one flask $(0.3$ to $0.7 \mu \mathrm{g}$ per $\mathrm{ml}$ ), and both epinephrine and an equal weight of $\mathrm{PGE}_{1}$ were added to the paired flask. The tissues were homogenized and lipase activity and phosphorylase activity were assayed as described previously $(19,21)$.

$\dagger$ Results of 11 experiments, expressed as a mean of differences between pairs \pm standard error of the mean. 
sisting for less than 30 seconds, followed by a fall in pressure returning to control values over the course of the next 1 to 2 minutes.

\section{Discussion}

The studies reported above show that $\mathrm{PGE}_{1}$ is a remarkably potent antagonist of the fat-mobilizing action of catecholamines in vitro. At $2.8 \times$ $10^{-7} \mathrm{M}$ concentration, it was highly effective in suppressing the action of norepinephrine present at twice that molar concentration. Significant inhibition was observed at $\mathrm{PGE}_{1}$ concentrations as low as $5.6 \times 10^{-8} \mathrm{M}$. The lipolytic action of glucagon, ACTH, and TSH was also inhibited. The fact that less than stoichiometric amounts of $\mathrm{PGE}_{1}$ inhibited effectively and the fact that it inhibited the action of these several lipolytic hormones of differing molecular structure suggests that it does not act simply through complex formation with the hormones. The intimate mechanism by which the fat-mobilizing hormones lead to activation of the hormone-sensitive lipase in adipose tissue is not known. The most that can be said is that prostaglandin must interfere at some point in the pathway common to the several hormones whose activity it blocks.

Although the effect of $\mathrm{PGE}_{1}$ on hormone-stimulated activation of phosphorylase appears to be smaller in percentage terms than its effect on lipase activation, this direct quantitative comparison must not be considered definitive, since the absolute magnitude of the hormone-induced increments in enzyme activity, relative to control tissue, was not determined. Preliminary studies with rat liver slices failed to reveal any effect of $\mathrm{PGE}_{1}$ on epinephrine stimulation of glucose release.

Direct comparison of the potency of the different PGE compounds showed that $\mathrm{PGE}_{2}$, although it was active at relatively low concentrations ( 0.5 to $5.0 \mu \mathrm{g}$ per $\mathrm{ml}$ ), was less effective than $\mathrm{PGE}_{1}$ in blocking hormone-stimulated lipolysis. $\mathrm{PGE}_{3}$ was without effect at concentrations up to $1 \mu \mathrm{g}$ per $\mathrm{ml}$; at $16.6 \mu \mathrm{g}$ per $\mathrm{ml}$ it significantly reduced epinephrine-stimulated lipolysis. It can be concluded that all three PGE compounds are active, with potencies in the order $\mathrm{PGE}_{1}>\mathrm{PGE}_{2}$ $>\mathrm{PGE}_{3}$.

$\mathrm{PGF}_{1 \alpha}$ and $\mathrm{PGF}_{1 \beta}, 0.5 \mu \mathrm{g}$ per $\mathrm{ml}$, did not significantly inhibit epinephrine-stimulated lipolysis.
$\mathrm{PGF}_{1 \alpha}, 5 \mu \mathrm{g}$ per $\mathrm{ml}$, caused some inhibition, but $\mathrm{PGF}_{1 \beta}$ was still without effect at this higher concentration. The relative potencies appear to be $\mathrm{PGE}_{1}>\mathrm{PGF}_{1 \alpha}>\mathrm{PGF}_{1 \beta} . \mathrm{PGF}_{2 \alpha}$ was without significant effect at $0.5 \mu \mathrm{g}$ per $\mathrm{ml}$, but was active at a concentration of $5 \mu \mathrm{g}$ per $\mathrm{ml}$. Direct comparison confirmed that $\mathrm{PGE}_{2}$ was more potent than its $\mathrm{F}$ derivative, $\mathrm{PGF}_{2 \alpha}$.

The studies in dogs demonstrate the ability of $\mathrm{PGE}_{1}$ to suppress mobilization of FFA induced by epinephrine in vivo. There was, however, no apparent effect on the degree of hyperglycemia produced by epinephrine. Bergström, Carlson, and Orö (28) have recently studied the effects of $\mathrm{PGE}_{1}$ in vivo more extensively, making use of constant infusion techniques. Their results confirm the ability of $\mathrm{PGE}_{1}$ to block the FFA-mobilizing action of catecholamines. The availability of these potent inhibitors may be of help in further elucidation of mechanisms controlling fat mobilization. Catecholamines, ACTH, TSH, glucagon, and vasopressin increase the rate of lipolysis in adipose tissue, apparently by favoring the conversion of a specific hormone-sensitive lipase from an inactive to an active form $(22,23,25-27,29)$. All of these hormones similarly bring about an increase in phosphorylase activity in adipose tissue. The effects on phosphorylase activity are presumably mediated by cyclic $3^{\prime}, 5^{\prime}$-adenosine monophosphate (AMP), but the role of this nucleotide in the lipase system remains to be determined. Cyclic AMP is an intermediate in the effects of vasopressin on permeability of the toad bladder, and it has recently been shown that PGE inhibits the action of vasopressin in that tissue (30) just as it inhibits the effect of vasopressin on lipolysis in adipose tissue (29).

The potent vasodepressor action of $\mathrm{PGE}_{1}$ was confirmed $(6,14)$, and it was further shown that $\mathrm{PGE}_{1}$ sharply reduces the pressor effect of equimolar amounts of epinephrine and of norepinephrine when injected intravenously at the same time as the catecholamines. Since $\mathrm{PGE}_{1}$ alone in the dosages used is strongly vasodepressor, whether it interferes with the hormone-activated mechanism leading to contraction of smooth muscle or whether it simply causes vasodilation by an independent mechanism cannot be decided. 


\section{Summary}

Prostaglandin $\mathrm{E}_{1}\left(\mathrm{PGE}_{1}\right)$ at $2.8 \times 10^{-7} \mathrm{M}$ concentration effectively counteracted the fat-mobilizing activities of epinephrine, norepinephrine, adrenocorticotropic hormone, glucagon, and thyroid-stimulating hormone on the rat epididymal fat pad in vitro, measured in terms of glycerol release into the medium. In the absence of added hormones, the rate of glycerol release from fat pads was slightly decreased by $\mathrm{PGE}_{1} . \mathrm{PGE}_{1}$ interfered with the epinephrine-induced activation of a hormone-sensitive lipase in adipose tissue. There was also a small but significant interference with epinephrine-induced activation of phosphorylase.

The relative potencies of a series of closely related compounds in the prostaglandin family as inhibitors of epinephrine-induced fat mobilization in vitro were determined.

The high potency of $\mathrm{PGE}_{1}$ as a vasodepressor agent was confirmed. When injected intravenously into dogs along with approximately equimolar amounts of epinephrine or norepinephrine, $\mathrm{PGE}_{1}$ counteracted the pressor activity of the catecholamines as well as the rise in plasma free fatty acids normally produced. The hyperglycemic response to epinephrine did not appear to be altered.

\section{References}

1. Goldblatt, M. W. A depressor substance in seminal fluid. Chemistry and Industry (Lond.) 1933, 52, 1056.

2. Goldblatt, M. W. Properties of human seminal plasma. J. Physiol. (Lond.) 1935, 84, 208.

3. Von Euler, U. S. Zur Kenntnis der Pharmakologischen Wirkung von Nativsekreten und Extrakten Mannlicher Accessoricher Geschlectsdrusen. NaunynSchmiedeberg's Arch. exp. Path. Pharmak. 1934, 175, 78.

4. Von Euler, U. S. Über die spezifische Blutdrucksenkende Substanz des Menschlichen Prostata- und Samenblasensekretes. Klin. Wschr. 1935, 14, 1182.

5. Von Euler, U. S. On the specific vaso-dilating and plain muscle stimulating substrates from accessory genital glands in man and certain animals (prostaglandin and vesiglandin). J. Physiol. (Lond.) 1936, 88, 213.

6. Von Euler, U. S. Weitere Untersuchungen uber Prostaglandin, die Physiologisch Aktive Substanz Gewissen Genitaldrusen. Skand. Arch. Physiol. 1939, 81, 65.
7. Bergström, S., and J. Sjövall. The isolation of prostaglandin $\mathrm{E}$ from sheep prostate glands. Acta chem. scand. 1960, 14, 1701.

8. Bergström, S., R. Ryhage, B. Samuelsson, and J. Sjövall. The structure of prostaglandin $E_{1}, F_{1}$ and $\mathrm{F}_{2}$. Acta chem. scand. 1962, 16, 501.

9. Bergström, S., F. Dressler, R. Ryhage, B. Samuelsson, and J. Sjövall. The isolation of two further prostaglandins from sheep prostate glands. Arkiv Kemi 1962, 19, 563.

10. Bergström, S., and B. Samuelsson. Isolation of prostaglandin $E_{1}$ from human seminal plasma. Prostaglandins and related factors II. J. biol. Chem. 1962, 237, PC 3005.

11. Bergström, S., and B. Samuelsson. Isolation of prostaglandin $E_{1}$ from calf thymus. Acta chem. scand. 1963, 17 (suppl. 1), 5282.

12. Bergström, S., F. Dressler, L. Krabisch, R. Ryhage, and J. Sjövall. The isolation and structure of a smooth muscle stimulating factor in normal sheep and pig lung. Arkiv Kemi 1963, 20, 63.

13. Änggård, E., and B. Samuelsson. Smooth muscle stimulating lipids in sheep iris. The identification of prostaglandin $F_{2 \alpha}$. Biochem. Pharmacol. 1964, 13, 281.

14. Bergström, S., H. Duner, U. S. von Euler, B. Pernow, and J. Sjövall. Observations on the effects of infusion of prostaglandin $\mathrm{E}$ in man. Acta physiol. scand. 1959, 45, 145.

15. Steinberg, D., M. Vaughan, P. J. Nestel, and S. Bergström. Effects of prostaglandin E opposing those of catecholamines on blood pressure and on triglyceride breakdown in adipose tissue. Biochem. Pharmacol. 1963, 12, 764.

16. Vaughan, M. Effects of hormones on glucose metabolism in adipose tissue. J. biol. Chem. 1961, 236, 2196.

17. Vaughan, M., and D. Steinberg. Effect of hormones on lipolysis and esterification of free fatty acids during incubation of adipose tissue in vitro. $\mathrm{J}$. Lipid Res. 1963, 4, 193.

18. Korn, E. D. Clearing factor, a heparin-activated lipoprotein lipase. I. Isolation and characterization of the enzyme from normal rat heart. J. biol. Chem. 1955, 215, 1.

19. Lambert, M., and A. C. Neish. Rapid method for estimation of glycerol in fermentation solutions. Canad. J. Res., E 1950, 28B, 83.

20. Dole, V. P. A relation between non-esterified fatty acids in plasma and the metabolism of glucose. J. clin. Invest. 1956, 35, 150.

21. Vaughan, M. Effects of hormones on phosphorylase activity in adipose tissue. J. biol. Chem. 1960, 235, 3049.

22. Vaughan, M., and D. Steinberg. The epinephrinesensitive lipase of rat adipose tissue. Fed. Proc. 1963, 22, 303. 
23. Vaughan, M., J. E. Berger, and D. Steinberg. Hormone-sensitive lipase and monoglyceride lipase activities in adipose tissue. J. biol. Chem. 1964, 239, 401.

24. Duncombe, W. G. The colorimetric determination of long-chain fatty acids in the 0.05-0.5 $\mu$ mole range. Biochem. J. 1962, 83, 6P.

25. Hollenberg, C. H., M. S. Raben, and E. B. Astwood. The lipolytic response to corticotropin. Endocrinology 1961, 68, 589.

26. Rizack, M. A. An epinephrine-sensitive lipolytic activity in adipose tissue. J. biol. Chem. 1961, 236, 657.
27. Björntorp, P., and R. H. Furman. Lipolytic activity in rat epididymal fat pads. Amer. J. Physiol. 1962, 203, 316.

28. Bergström, S., L. A. Carlson, and L. Orö. Effect of prostaglandins on catecholamine-induced changes in the free fatty acids of plasma and in blood pressure in the dog. Acta physiol. scand. 1964, 60, 170.

29. Vaughan, M. An effect of Pitressin on lipolysis and on phosphorylase activity in rat adipose tissue. Amer. J. Physiol., in press.

30. Orloff, J., J. S. Handler, and S. Bergström. Unpublished observations. 